\title{
Defeat Depression in Adherence to Spiritual Pathway in Bhagvad Gita
}

\author{
Dr. Ku. Richa Shrivastava \\ Ph.D. \\ Indian Institute of Technology \\ Roorkee, Uttarakhand, India \\ richashrivastavaiitroorkee@gmail.com
}

\begin{abstract}
Dhritrashtra desires to know about the battlefield of Kurushetra. Dhritrashtra is inquisitive in relation to the combat zone. He denotes his sons as Kauravas and his brother's son as Pandavas. He enquires Sanjay, "What my sons Kauravas and my brother's sons Pandavas are doing in the war arena. He is concerned about his sons and calls them "Mine". He is not worried about his brother's sons and calls them "Others". The way Dhritrashtra's is characterized, it represents one thing that is his psychology, it's critically analyzed his personality by his words. When he speaks something about war frontline his emphasis is on the words, "My sons". When a person defines himself as "Me" and "Myself" and describes the others as "You" and "Yourselves". Here the quarrel begins. Duryodhan is Dhritrastra's son, whatsoever is the nature of Dhritrashtra, and broadly the son also has the same behavior. He said, "What my lads and Pandava's lads are doing in the war - front", from now, excess of love and affection towards his sons is revealed. He cogitates that, "Either, I ought to reign the country, or my sons might sovereign the nation, and no one else should be the supreme ruler. I would survive and my sons should subsist. My all possessions are supposed to stay secured and others should be empty handed. This is the
\end{abstract}


language of self -centeredness. Dhritrastra had the mean mentality. Great writers have printed their writings, about those who notify these clothes are mine, these houses are mine, these jewels are mine, these are my eatables, these are my resting places, those whom speak everything is mine, the persons whom emphasize themselves by the words, "Me" and "Mine", the evil deaths are sure for those persons, they will die badly. A writer has very beautifully depicted in a few lines, the way it is written that has been told. This is not the sayings of a saint. It's just like a meaningful sequence, some lines have been written in verses. Let's visualize;

The goat which utters "me, me" get's its cut throat from the knife.

And the Indian bird, "meina", which utters "me not", is liked by everyone.

Indian citizens are very much fond of this column. Everyone likes the bird, "meina", because it utters, "Me not" i. e. "meina" in dialectal language Hindi.

"Me - Not" represents, "I am nothing", which delineates, "I am not superior to others", if we also do not have pre-eminence intricacies and if we utter these declarations before Almighty, that "I am a person who is below in dignity, I am nothing in front of others. I am not special, and then the world will be gratified by you, as well as the creator of this cosmos will also get astonished by you."

Keywords: Meina: Me Not, Grantha: Spiritual Book, Agni Puran: A Holy Book of Hindus.

Dhritrashtra is talking about "me" and "mine", most of the times, if we discuss his ego problems, it will take a long tenure. If we discuss Bhagvad Gita in brief, it will take near about twenty - twenty four research papers and that will take near about two years. It's not that easy, so in brief; considerably, I will deal with depression. 
Kurushetra is a land of martyrs; it exemplifies that till there is life; we have to do good deeds. We have to bear our responsibilities. We have come to this planet to fulfill our responsibilities. We have to do favorable tasks till our last breath. We do not have to sit idle.

In Mahabharata, the battle - ground the natives who have stood are of old age and as well as of very young age. For Example - Abhimanyu, he is of sixteen years old and Bhishma, he is elderly. The ages of Abhimanyu and Bhishma are incompatible. All of them, Kauravas and Pandavas have fought against one another in the combat zone. There is "Struggle" in the warfront. In life - time if there is mature and if there is juvenile, the fight is with both of them. From the first breath the effort starts, till there is last breath, the resistance never stops.

In your body, there is always clash between good bacteria as well as bad bacteria. Till when the good bacteria which promotes health and well-being are able to resist against bad bacteria, till then we are hale and hearty. There are many diseases which are always inside us. The bacteria of tuberculosis are always there. It gets provoked in people who have lost their vitality. It's confirm as soon as we lose our vivacity; these bacteria will grow and it would harm the body.

Remember that, if you have strong verve, you will be able to live long life. The people who take deep breath in their sleep, they live long. We have to strengthen our liveliness, take deep breath and laugh whole - heartedly; we have to do exercises till we sweat. Always follow routine in order to live long life. As we have come to this world to do efforts successfully. Shashtras delineates that we should drudge, as this body has been given to us by Almighty to perform well. The physical features which are given to us by supernatural being, especially the hands from which we have to toil. 
We are standing on this Earth, as we are here to fulfill our duties. We are the doers. We have to get busy ourselves by doing beneficial tasks. In accordance to Hindus, vitality has been divided into four ashrams that are four stages, whether it is first stage, Bramhacharya Ashram that is bachelorhood, second stage, Grihastha Ashram that is life of the householder, third stage Vanprastha Ashram that is retiring to forest and the fourth stage, Sanyasa Ashram that is the life of an ascetic. The word "Shram" is associated with all of them. This word indicates that we have to gain excellence in our occupation; we do not have to operate effortlessly. We have to be the doers of tough operations. We are not allowed to be seated at leisure. We have to exert to stay alive.

We all have the life situations like Kurushetra warfare. All of us have conflicts in life time. Only those castes and communities survived, which were dedicated to their works. In all the books of history, rulers of any caste about them have been discussed. The populace those who were dedicated to their jobs and those who were brave that castes and communities which were disciplined, those progressed. Then ruling class become lethargic, those groups got involved with cultural materialism. They started loving the comfort, their progress got declined. Hence the time has come they could not regulate themselves so they could not impose authority on others. The same rulers got defeated by others; i.e., working class population and their culture declined.

Keep this in mind, till when you will do hard slog, you will proceed forward in your existence. Till when you will face cut throat competition your dynamism will prop up you to get ahead.

In Mahatma Buddha's life an incident occurred. Mahatma Buddha has been crossing any forest by the passage. He has seen in one place that a very beautiful plant with soft leaves has 
bloomed. Mahatma Buddha has observed the greenery of the plant and commented about the plant to Ananda. This plant has vitality, it is full of liveliness. This plant will endure; it will grow and turn into a gigantic tree. Ananda twisted back, he has noticed the plant and then he uprooted it. Mahatma Buddha has shifted back and looked at the plant, he has perceived that Ananda has extirpated the plant; he beamed and asked to Ananda, "Do, you want to examine its liveliness?" Then and there, Ananda leaves that plant in the soil and moves forward. After ten to twenty days, Mahatma Buddha has arrived back, he indicates him, "To go now and spot that plant, it was bending over in the soil. At that stooped position, its roots started to hold the soil. The plant sustains loam and blossoms there.

Mahatma Buddha conversed to Ananda, similarly, like the plant, the personalities who are full of vivacity, world may throw them from the top most position to the lower most position. Whenever they will fall, they start rising from there only. Make your determination very strong. Always retain this information, if we lit the flame of fire in the lowest point, even then in the nadir position, it will rise upwards. Once make a determination, thereby keep this strength in your mind that I have to reach the zenith, you will definitely achieve the highest point. That's why it is said -

Humans are born in the Universe to rise above and to achieve the zenith, then after get praised. Human beings are not born in this world to go downwards to the nadir point and feel disgrace. From darkness to go towards enlightenment, this is your life goal. Come out from your denunciation, and do not be a loser. Heal your depression.

In war field of Kurushetra the warriors of both the armies have reached and they took position in campaign. Dhritrashtra again inquires, Sanjay from his divine vision to inform him the truth about the hostilities. Lord Krishna has become the chariot driver of Arjun who is 
standing in the war front. Arjun asks Lord Krishna to take his chariot in the presence of the fighting legions. He wishes to acknowledge who all are fighting against him”.

Whilst egocentricity arises within the folks, it's very strange, family members those are in blood relations stand against one another. Once; there are selfish motives, even the teachers might not favor their students.

Remember this, on every time there is a phase of struggle, most of the times you will always find yourself alone. At that time choose your guide as God; do not select anyone else as your administrator. During loneliness Arjun's administrator is Lord Krishna. Arjun views all the people of combat zone in front of him as his enemies and supporters of the Kauravas. In them, there are teachers who have taught all of them as well as there are relatives who have looked after both the family groups: the Kauravas and the Pandavas.

One of them is their paternal grandfather Bhisma Pitamah, also in whom lap Arjun has played. In childhood, several times, Arjun has relished Bhim's Kheer and to save himself from his brother Bhim, he has been familiar with Bhishma Pitamah and sits in his lap. Bhisma at ease with him put his hands on Arjun's head and thereby blesses him with love and said, "You are a naughty kid and should I save you?" All memories are at the heart of Arjun.

Guru Drona - Acharya is also positioned with Kauravas in against of Arjun, i.e., Pandavas. Arjun hardened to bring pitchers of water for him and served Drona - Acharya. He has been accustomed to clean his courtyards as well as wash his feet. He has been in the habit of coming in a hurry and arriving early at the classes of Drona - Acharya to learn more than other students. Drona - Acharya also conditioned to say to him with fondness, "Arjun you will not leave any skill left with me. You will learn all of my teachings". Those reminiscences are within him. At front of him is his Guru Drona - Acharya. 
Kripa - Acharya is Kulguru, he is also has his stance against Arjun. Kuntin Maa used to bring her sons to give best upbringing by the preaching of Kripa - Acharya. Pandavas visited him to inculcate best virtues. These are also the recollections.

King of Bhadra country, Shailya is the maternal uncle of Lord Krishna as well as maternal uncle of Arjun, these all were standing in the side of Kauravas. Those who were brothers, those who were maternal uncles, those who were paternal uncles, those who were great grand - fathers all the consanguinities of those ages, Arjun has noticed all these associations are in the side of Kauravas.

Arjun has been in this belief that, "Everyone who sought to ascend the throne has been in eminence against Pandavas. One and all required this land to rule over it".

In Agni Puran there is a quotation - When the Earth cries? And when the air laughs?

It is well said when the men's arrogance rises up to zenith then the air laughs and then air says, You are flying very high in the sky, you do not discern when you will fall and reach at nadir point. When the native measures the land and declares, that, "I am the owner of this land". Then the land cries, "You are my son, you have measured me and you are wrong to proof your owner ship over me. You will measure me correctly on that day when you're dead body would lie on this land. You will not be able to measure more land than your dead body. You consider yourself to be my owner. My owner is the creator who has created me."

Arjun has also reflected about it. For the ownership of this land, to seize the throne, for better facilities and luxuries, these Kauravas are ready to murder someone. They are prepared to fight and kill the others. Thereby, they are in favor of cut throat competition. What kind of society is this? They all have forgotten family bonds. Those who used to say, son, we love you more than our lives. What has happened to them? Every being's eyes have changed. Self-seeking 
purposes are before them that's why they have prominence against Arjun who comprises of Pandavas.

In this condition, Arjun felt heartbroken and he has uttered - "My body is shivering and my mouth is dry. My life is indolent. My every pore is sweating. I am in shock. What all these are happening? Which type of most people have reputed against me? I have to fight against all of them. Again, Arjun said: "We do not wish to rule the empire". He had been in mood disorder. He felt like kicking off himself. He felt his life is worth damn. He reproached his mind. He reprobated this world. He felt rebuked to gain ownership of the kingdom. He got his mood imbalanced because the Kauravas have come to fight for this land with the entire clan has been against Pandavas.

Arjun has addressed his grievances in this manner to Lord Krishna - Oh Govind! What's the worth of that empire? When I have to kill my own relatives to reign the throne and acquire wealth and materialism, is there any benefit?

This verse of first chapter depicts Arjun's mentality. Oh Krishna! I do not want to be victorious; I do not wish to be successful. I do not want to rule the state; I do want these comforts and luxuries the whole world is running after them. If I have to kill my own people for our welfare, why should I rule over this state? The person wants wealth and govern the kingdom for his nears and dears. Human wants to earn money for his blood relations. Thence, those people are in front of me to battle unto death. What I will do to be a regent of such a territory? Why I would wish to be successful for such lavishness? That's why I do not wish to encounter the rivals for such wealth.

Consider this, the way we feel, our emotions are formed in that manner. Similarly, we give such logics. If we are not able to do anything, we speak; the way it is destined, we must wait 
for it, because we could do nothing, we are unsuccessful. At that, we could make ourselves understand whatever is with us, is that less? It's alright, grapes are sour; the way we feel, we make others understand our approach. If some women reveal her too much bosom or if some men expose themselves as nudes, they do not feel ashamed of their sexual organs. They have the feelings like tribes. They proclaimed: we have come to this nature like this. They make others grasp that, "Why females should feel shy or why males should cover up themselves. There is no benefit in these ways. If some people follow different dress styles than the general tradition, they will proof their dressing sense is accurate and ladies would advise others to reveal themselves or men would advise others to expose themselves. It means that our intentions are formed systematically, we also advise others in parallel context. We evidence the others same as, we think ourselves to be correct.

Commit to memory, this would happen for sometimes only. At the end, when we imagine about them, their reality is examined. We know, we have said such things for the sake of others, to explain others but we could never ever run away from ourselves.

Arjun is also in the similar condition - Lord Krishna understands his conditions. After some time, he would come back in his nature. His motto is to mention such things for the time has been not in his favor, he has averred that he wants nothing, he will remember back the misdeeds, which has happened with them all the days. He will remember back the days which they have spent in the forests. He would also remind of that, how they have been in disguise to conceal their identities not to get revealed in front of Kauravas. He knows how they have borne so much hurt and affliction? He could not forget the disrespect which his cousins have shown to his wife Draupadi. Pandavas could not forget how the Kauravas attempted to burn them alive in 
the superb palace; Laksha - Griha, they escaped from the palace before it could be burnt down. Lord Krishna has known Arjun; Then after, he will get excited to take avenge Kauravas.

Assume about it, if doctor reaches in the operation theatre and tells that - "What is the benefit of operation, there will be blood loss. It's not good to cut off someone's body". What we would tell to that doctor, we will say, "Respected doctor, please correct your mind set up, at least we wish to do away with that person's ailment by surgery. We didn't ask you to cut the body, we have asked you to cut off the diseased part of the body". This is the reality. Lord Krishna considers Arjun as a surgeon and expects him to cut off the diseased organ of the society. Thereby, the society will be acceptable, if we do away with the bad people who have arisen against the high values and good morals of the society. Likewise, gardener removes thorns from the plants in the garden to make the surroundings look pleasant. In the same manner, if the tailor wants to stitch the new clothes with nice get up and correct fitting. He would primarily cut off the clothes and then; secondary he will stitch it. If we have to make a new building, firstly, we have to break down the old building and secondly, we must construct new one. If we want to induce the good moral values in the society, we have to remove the old and obsolete hurdles of the society. If we wish to inculcate positive thinking in the society, we have to remove off the people with ill mentality so that the colonies could be established with new ideas and high moral values. The nature also renews itself by shedding of the old yellow leaves so that the new tiny green leaves could be grown in the spring season. Until, when the obsolete traditions could not be removed, how the new traditions could be stimulated in the civilization? Attempts should be made to renovate the social order. When there is no else medication is possible. All the medicines have been prescribed which did not work; then doctors do surgery in the emergency conditions. Pandavas have done all gracefulness; they tried to impress Kauravas by all methods. They also 
have prayed them. Even then, Kauravas didn't agree. Pandavas have begged them just to give them five villages out of the great dynasty of Hastinapur they would not fight with them. All possible tactics have been done. Then, Lord Krishna has understood; that in analogous situations, the empire could be gained back by only declaring the war against Kauravas. No option is left. Thereby, Lord Krishna has given discourse to Pandavas on why to fight the war? How to resist against them and why they should go in this direction towards attack?

Before this, our priority is to construe that - What ensues in depression? Arjun is in melancholy, he is in depressed state of mind. He wants to run away from his duties as he has got moved away his chariot from the battlefield where he had to stand and fight. He is sitting on his chariot and has shown his back towards the conflict.

Many times, this happens that men wish to run away from their predicaments. We have noticed most of the times that housewife keeps telling their setbacks to their husbands at home. Thence, while eating food, they pretend to listen to difficulty and just articulate yes to all complexities and in reality, their husbands ignore all these complicatedness. They look here and there and they would not respond to the quandary. He would not attempt to withstand the crisis. Whenever, they will get the time, they will postpone such talks for the future by asserting their wives, "They always discuss the same circumstances every now and then, when we sit, when we get ready, when we go to sleep all the times such discussions”. Males want to get away themselves from the intricacies and their wives, who are trying to solve their tense state; they always seek the help of their husbands to suggest them solutions. Utmost, men ignore families' problematic plight.

We all have habits like pigeon to see the cat and close the eyes because; it could not do anything else. Pigeon closes the eyes because it thinks that the cat might ignore it, but if it does 
this the hurdle is not resolved. As pigeon is afraid of cat, we humans are afraid of our tensions and we try to ignore our hurdles. We endeavor to run away from our obscurities as correspondingly cat does not leave the pigeon our stress also does not leave us. Yes, to escape is not the solution; to get awakened is the resolution. It has to be aware of the fact. It's correct that cat is very powerful, it could catch the pigeon and thereby cat may kill it. God has given powers to pigeon also and its power is the wings it could identify with the threat and fly high in the sky. Then, cat could not harm the pigeon. Cat will stay on the ground; it could fly high and higher in the sky. Thus, it could escape death.

That's why; Lord Krishna does not refer, "to run away from the hurdles". He speaks, "to get awakened amidst the sticky instance". If we aim to run away from the crisis, it will never end. People get addicted to alcoholic drinks and with the help of intoxicants they wish to forget their dilemma. In reality, they do not forget their dilemmas, but they get addicted towards the wrong habits.

When they have done away from the intoxication, they come to know, yet there are the same incidents. They again drink to lose consciousness, so they can forget themselves. The life of animals is of ignorance, so they can forget about themselves. We undertake wrong path by taking intoxicants because we do not want to face the quandary.

It's very strange, that in our legs thorns have been struck and instead of taking them out, we put efforts in bandaging them, this activity is very different.

Old grandma has lost her needle at home. It was dark so she went out in the street. There has been electricity in the street and no electricity at home. Everyone inquires her, "What are you searching for? Elderly, grandma replied, "I am searching for the needle". People asked, "Where it has been lost?" She said, "At home". Gentry asked, "Where are you searching for it?" She 
replied, "Outside in the streets". Crowd raised, question "Why are you searching it out?" Old Grandmother replied, "There is darkness at home, I could not search it there. Here it's bright, so I am searching for it on roads". You would definitely declare that "Grandma is very strange, but in reality human beings are also very strange in related behavior.

If we observe, we all are strange people. Where there are circumstances, we are not trying to solve the problems with that person or at that place. We will not do our deeds. In front of palmist, we will show our hands and ask them to predict our destiny. We do not want to work hard and earn money. We believe and excuse ourselves by the way of gambling, by this method, we should make large money.

Thence, Lord Krishna is the Guru who preaches that we should live in this world. But we should not get entangled in this worldly quagmire. He said, Do not run away from this world. Get awakened. When we awake the things will start taking place properly. Strive to recognize the problems appropriately; endeavor to know your capabilities. Point out what is the hurdle? Find out where does the tension lies? When you do realize where does the setback lies? Then with all your might remove off the obstacles with hard task. Thereby, attempt to come out completely from the crisis. If it's unclear in this way, please comprehend in this mode - if the thread gets a knot, then do not apply pressure, do not pull them out, the knot will become stronger and the threads will get affixed more tightly. First of all, keep it in front with concentration watch that, from where it is strongly tied and affixed from there try to loosen the thread.

Firstly, try to judge yourself where you are entangled in this worldly quagmire and what are the reasons beyond them? Then, attempt to loosen yourself, seek to resolve the problem from where you get entangled? Where the knot is affixed, you have to loosen the thread there. 
Similarly, to resolve your problem, you need not to go anywhere else? If you are lured in this world, you have to overcome complexities since here only. Commencing, where you get messed, there you have to seek out the resolution. The quandary will be resolved yet you are depressed you will not be able to do anything. In today's world, the depression is one of the greatest predicaments. It is called a disease. When a person is not able to sleep properly and even if someone sleeps one gets awakened in the midst of sleeping time. In the evening, depression gets exaggerated, a person turns out to be angrier, more irritation occurs, and because of depression the person becomes disheartened. In loneliness either the person gets terrified or starts weeping. A person does not like to chatter with anybody, one likes solitude. This condition is known as that the person has become worried and doctors called it depression. When it gets enhanced the medical science explicates the affect. From, when the person awakes in the morning the one feels uneasiness and the mind has symptoms of mood disorder. In general, people feel freshness while they get up early in the morning. Since, morning the person feels annoyed then it is examined that the depression has become chronic. Here, thither everyone would approbate to know the remedy.

Lord Krishna has healed Arjun. As soon as the person gets hurt, treatment is necessary at that moment. In such ailment, the medication of doctor has to be acquired, but that is less effective. Ten percent is the effect of medicine, for the ninety percent you have to make arrangements for your own health. If a person is suffering from depression that person must not be left alone. Do not let that person sit in loneliness. Most of the times that person will feel gloomy, he or she would like to listen to the sad songs. The feelings which bring tears to eyes the patient feels more adhered to it. If someone will crack a joke, or if someone would narrate something in relation to happiness or gaiety, the despondent would not like to hear to it. Do not 
leave such person in depression. Make him or her busy, let that worried being sits amongst children, because they make laugh to a depressed being. Make the depressed person to do work. Take that person near to nature. A person who is stressed must drink more water. The person must work in the area in which he or she is interested. The neighbors, nears and dears must be made aware that the person is a patient and they must empathize and sympathize, be humane to the sufferer. In this manner, treatment must be undertaken. Concentration and meditation are the most important medicines for that person; thereby that one should practice concentration and learn meditation.

We discuss depression in context to today's world. We must understand the depression of Arjun two thousand and two hundred years back, he was in depression for some times. Lord Krishna has awakened him from depression and this spiritual awakening is not only for Arjun, it is for the entire humankind. Lord Krishna has shown the pathway for the entire human race to overcome depression. Therefore, keep in mind that human beings must understand the spiritual awakening. People think that Bhagvad Gita is a grantha which should be preached to the person who is approaching death. Bhagvad Gita is considered pious of all granthas because it reduces negativity and promotes positivity. All the problems and sorrows get away by the reading of Gita for all of them. Gita is a grantha which promotes welfare and well being of every being. Therefore, we may call Gita as an elixir grantha for mind and soul transformation. 


\section{Works Cited}

Agnipuran.net

BhagvadGita.net

C. Rajgopalchari. Mahabharat, Mumbai: Bhartiya Vidya Bhawan Press. 2015. Print.

“Om Namo Bhagavate Vasudevaya - Moksha (Liberation Mantra) meaning”, www.Awakeningstate.com 2020 Web 17 Feb 2020.

www.awakeningstate.com/spiritual-awakening/com... Web 17 Feb 2020.

“Ramayana: Asia Society”. Asiasociety.org. 2020 Web 17 Feb 2020.

https://asiasociety.org/education/ramayan.Web 17 Feb 2020

“Shastra: Hindu Scriptures”. Hinduonline.com 2020 Web 13 Jan 2020.

http://hinduonline.co/Scriptures/Shastras.html.Web13Jan2020.

Sudhanshuji Maharaj.net.

Swami, Prabhipada, A. C. Bhaktivedanta. Bhagvad Gita as it is, Watford: ISKON Reader Services, 2010. Print.

“Vedanta Concepts and Application”, Kolkata: Ramkrishna Mission Institute of Culture, 2000. Print. 